\title{
OFFICIERS DE SANTÉ: THE SECOND-CLASS DOCTORS OF NINETEENTH-CENTURY FRANCE
}

by

\section{ROBERT HELLER*}

In the last decade of the eighteenth century medical education and medical practice in France were in a parlous state. The Revolution had left the whole edifice of the art of healing in ruins. The Constitution of 3 September 1791 had laid down the principle of a complete re-organization of public education to take account of the changed conditions of French society. ${ }^{1}$ In 1792, however, after the radical faction of the leaders of the Revolution had come to power, the universities, learned societies, and the teaching corporations were abolished. Thus all the official teaching and licensing institutions of the ancien régime were swept away. ${ }^{2} \mathrm{~A}$ state of chaos resulted inevitably from the absence of governing bodies. The administrators of some French départements, anxious to protect the public from some of the worst excesses of charlatans, set up unofficial examination boards. Eventually the University of Montpellier illegally issued provisional licences to persons who had passed its examinations, and the two other French medical faculties of Paris and Strasbourg followed suit. These provisional registrations were officially recognized in $1797 .^{\circ}$ The need for medical personnel for the army and navy became increasingly urgent and in the first place a system of medical education had to be established. Fourcroy, the eminent scientist and educator, furnished a long report at the end of November 1794 and early in December of the same year the National Convention promulgated the law of 14 fimaire year III (4 December 1794). ${ }^{5,6}$

The law of 1794 decreed that three schools of health (écoles de santé) be established in Paris, Montpellier and Strasbourg to produce medical personnel for hospital

*Robert Heller, M.D., Wellcome Institute for the History of Medicine, 183 Euston Road, London NW1 2BP.

${ }^{1}$ Senator Bonjean's Report to the French Senate at the session of 12 April 1864 in Gaz. hebd., 1864, 16: 262-264, 17: 283-288, 18: 302-303, see pp. 262-263.

David M. Vess, Medical Revolution in France 1789-1796, Gainesville, Fla., University Press of Florida, 1975, pp. 54-71.

'H. Montanier, 'Médecine, enseignement et exercise', in A. Dechambre (editor), Dictionnaire encyclopédique des sciences médicales, 2nd series, Paris, Asselin \& Masson, 1872, vol. 5, p. 667.

- Antoine François de Fourcroy (1755-1809) qualified as doctor of medicine, but his main activities lay in the fields of chemistry and of education. His attitude at the time of Lavoisier's trial has been questioned. He seems, however, to have done all he could to save Lavoisier's life. (See Charles Gillispie, 'Notice biographique de Lavoisier par Madame Lavoisier', Rev. Hist. Sci., 1956, 9: 54-66.) His important role in the history of medical education is shown in his plans for the French laws of 1794 and 1803. (See William A. Smeaton, Fourcroy, chemist and revolutionary, 1755-1809, Cambridge, Heffer, 1962, pp. 1-91; Erwin Ackerknecht, Medicine at the Paris Hospital 1794-1848, Baltimore, Johns Hopkins University Press, 1967, pp. 33-34; H. C. Barnard, Education and the French Revolution, Cambridge University Press, 1969, pp. 216-222.)

b Auguste Corlieu, Le centenaire de la Faculté de Médecine de Paris (1794-1894), Paris, Imprimerie Nationale, 1896, pp. 1-8.

- Vess, op. cit., note 2 above, pp. 152-169. 


\section{Robert Heller}

service, especially for military and naval hospitals. The outlines of a curriculum were established which provided for a medical education far in advance of that which the ancien régime had had to offer. These courses were not only to be open to the students selected by the state, but also to any others. The number of professors and their assistants for each school was established as well as the provision of libraries, museums of anatomy and natural history, laboratories, etc. The time of opening these seats of learning was fixed and the professors and their assistants were exhorted to perfect their knowledge by research without any slackening. The schools of surgery in the three cities where écoles de santé were to be situated would be integrated into the latter.

As there had been no selection of students in force, this problem presented some difficulties. Fourcroy attempted to solve it in the following manner: From each district of the Republic there was to be nominated one citizen between the ages of seventeen and twenty-six years, amongst those not liable to immediate call-up to the armed forces. Three hundred of these students would be allocated to the school at Paris, 150 to that at Montpellier, and 100 to that at Strasbourg. In the principal town of each district the Committee of Health would choose two health officers. ${ }^{7}$ These would be joined by a citizen, "commendable for his republican virtues" and who had been nominated by the Directory of the district. These three men would select the one prospective student according to his "civic virtues" and his knowledge of one or more subjects of a preliminary medical course. The chosen candidates would be required to report at their respective schools at a certain date and would receive a travelling allowance according to the rank of gunner first class. On arrival at the school the students would be divided into three groups according to the education they had previously received. The students would be given a grant for a period of three years. Those students who had acquired sufficient knowledge of the art of healing, would be employed by the Commission of Health in the hospital service or in the armed forces.

The law of 1794 laid the foundations for the subsequent flourishing of French medicine ${ }^{8.9}$ during the first half of the nineteenth century. The new system laid great stress on practical training as opposed to the dominantly theoretical schooling of the ancien régime. It was however fairly slow in producing medical practitioners and the supply of manpower for the armed forces and for the civilian population, especially outside the larger towns, became an increasingly serious problem. The Napoleonic wars created an insatiable demand for doctors, surgeons, and also for practitioners with lesser qualifications.

There was also a most important piece of legislation still outstanding. There was no law regulating the practice of medicine and midwifery in France, taking into account the conditions that had been changed by the Revolution. It fell again to Fourcroy to draw up a plan for a law that would govern the practice of medicine and at the same time, by creating a grade of lesser practitioners, increase the medical manpower in the country. Apart from his teaching and his chemical researches, Fourcroy had been

\footnotetext{
7 During the Revolution the title of doctor was not used. This was to emphasize the equality of all citizens of the Republic. Any person engaged in treating the sick, whether duly qualified or not, whether in a military or civilian capacity, would be addressed as officier de sante. This meaning of the word was changed by the law of 1803 (see note 13 below).

- Ackerknecht, op. cit., note 4 above pp. 31-32.

- Vess, op. cit., note 2 above, pp. 160-166.
} 


\section{Officiers de santé}

involved in the administration of learned societies during the ancien régime. The Revolution enabled him to put his ideas on education into practice. In contrast to his friend and fellow-scientist Lavoisier, he survived Robespierre's reign of terror and became Councillor of State under the Consulate of Napoleon Bonaparte. He produced the blueprint of the law of 19. Ventôse, year XI (10 March 1803). ${ }^{10,11}$

Although it shows signs of having been drawn up in great haste, the law is a most interesting document. It illustrates the great difficulties under which Fourcroy had to construct it and the many special circumstances that had to be considered. In the first place there was chaos as far as medical practice in France was concerned. The position of the physicians and surgeons who had been registered under the ancien régime had to be safeguarded, as well as that of the practitioners who had served in the armed forces. Equally, the practitioners in the occupied territories had to be considered. The main task, however, was to erect a firm legal framework for an orderly practice of medicine, surgery, and midwifery, and to define some standards of training. Into this system the existing practitioners had to be integrated, but in future unqualified practitioners had to be strictly excluded. Over and above these provisions a new order of practitioners had to be created and their training, examination, and the limits of their activities had to be determined. Finally, penalties for contraventions of the law had to be introduced. The manner in which Fourcroy dealt with these problems under most difficult circumstances seems to justify the reproduction of the law of 1803 in its entirety as an appendix (see pp. 39-43), It was to remain the main piece of legislation governing medical practice in France for nearly an entire century until the year 1892 . It consisted of the following provisions:

\section{FOURCROY'S LAW OF $1803^{12}$}

Articles 1 and 2 make it unlawful to practise medicine in France without proper qualifications, neither as a doctor or surgeon nor as officier de santé, ${ }^{18}$ and defines the titles of doctor of medicine or surgery, having qualified from one of the six medical schools to be set up ${ }^{14}$ as well as that of officier de santé, qualified after examination by departmental examination boards.

Article 3 confirms the right of all persons who had been registered in France before the Revolution, as well as of those registered in the territories recently occupied by the French Army to practise, provided that they were holding a legally recognized degree.

Article 4. The government might confer the right to practise in France on graduates

10 Charles Coury, $L$ ' enseignement de la médecine en France, des origines d nos jours, Paris, Expansion scientifique Francaise, 1968, pp. 117-118.

${ }^{11}$ Ackerknecht, op. cit., note 4 above, pp. 38-39.

${ }^{12}$ Recueil Sirey, Recueil général des lois et des arrêts, 1st series, vol. 1789-1830, Paris, Administration du recueil genéral des lois et des arrets, 1851, pp. 622-623.

${ }^{13}$ This article of the law changed the meaning of the word officier de sante. As from the passing of this law the word described a medical practitioner of the "second class" (médecin de deuxiéme classe,) who, after a prescribed period of studies or of apprenticeship, having passed the appropriate examinations, was entitled to practise medicine, subject to certain restrictions.

${ }^{14}$ Only three medical schools were established on French soil at that time. They were founded at the medical faculties that previously existed at the universities of Paris, Montpellier, and Strasbourg. Two more were created in occupied territories, in Mainz in Germany, and in Turin in Italy. The sixth university remained only a project. (See Montanier, op. cit., note 3 above, p. 667, footnote 2.) 


\section{Robert Heller}

of foreign universities. ${ }^{15}$

Articles 5 and 6 determine the number and subjects of the qualifying examinations.

Article 7. The theses for the doctorate could be written in Latin or French.

Article 8. The duration of medical studies would be four years.

Article 9. Details of admission to the schools and of the instruction there would be determined by a future regulation.

Article 10. Persons who had studied at medical schools before the suppression of the universities, but, for that reason had not been able to take the examinations, would be able to take these now with a view to registration.

Article 11. Physicians and surgeons, not registered, but having served in the armed forces for two years in a commanding position or as officiers de santé first class, should receive the degree of doctor after having to pass the last stage of the final examination only, or after having submitted a thesis.

Article 12. Those students who had studied at the schools of health which had been established in 1794 and who had passed their examinations there, would receive the diploma of doctor of medicine.

Article 13. Only the national scholars, chosen by public competition, were exempt from paying fees for tuition and registration. ${ }^{16}$

Article 14. Makes provisions regarding the salaries of the teaching staff and the upkeep of the schools.

Articles 15 to 21 establish the new grade of the médecins de deuxième classe, the officiers de santé. An apprenticeship of six years with a doctor, or five years in a hospital, or three years' study at a medical school entitled the candidates to be registered as officiers de santé, after having passed certain examinations. For the purpose of these examinations, boards were to be set up in the principal towns of each département. The composition of the examination boards and the subjects of the examinations were established. Provision is made for those who had practised as surgeons during the past ten years without having been registered. They could now be registered as officiers de santé after due examination.

Articles 22 to 26 determine the procedures of local and central registration. Persons who had served in the armed forces in a subordinate medical capacity for three years or more were allowed to register as officiers de santé, as well as those who had practised in civilian life without qualifications for at least three years.

Article 27. Only fully-qualified physicians and surgeons, but not officiers de santé could be in charge of civilian hospitals or be appointed and sworn in by the authorities to perform official duties, such as those connected with public health, etc.

Article 28. Fully-qualified doctors could practise everywhere in France.

${ }^{16}$ Montanier, (ibid., p. 670), commenting on this article, suggests that foreign doctors should be allowed to practise in France only after having passed stringent examinations. These provisions of the law clearly had only been applicable at the time when France was occupying victoriously province after province and the doctors there had the right to practise their profession legally. Now, however, these foreign doctors, mainly German, Polish or Italian, proved to be dangerous competitors. They often attracted many patients just by being foreigners.

${ }^{10}$ The method of selection of state scholars had been changed to public competition from the original selection committee consisting of two health officers and one citizen "commendable for his Republican virtues". 
Article 29. The right to practise for the officiers de santé was restricted to the départements in which they were registered. ${ }^{17}$ They were not allowed to perform major surgical operations (les grandes opérations chirurgicales), without supervision of a fully-qualified practitioner of the same département. In case of serious mishaps arising from an illegal operation, the officier de santé would be liable to be sued by the patient or his relatives. ${ }^{18}$

Articles 30 to 34 regulate the training and registration of midwives. In case of a difficult delivery no midwife was allowed to apply instruments without having called in a practitioner registered under the old pre-revolutionary regulations. ${ }^{19}$

Finally, Articles 35 and 36 establish penalties for unlawful practice of medicine and midwifery. ${ }^{20}$

The grade of officier de santé came under attack mainly from the medical profession soon after its inception and remained under almost constant assault until its abolition. It managed, however, to retain its legality until the last decade of the nineteenth century. As social and economic conditions changed over the years, the demands for the creation of a single qualifying degree in medicine became increasingly urgent. It was thought that only one single degree, that of doctor of medicine, conferred by the medical faculty of a university, could ensure a sufficiently thorough and uniform training for the medical practitioner. Nevertheless it took ninety years from the passing of the law of 1803 until the title of officier de santé and that of doctor of surgery were finally abolished, although this issue was hotly debated in the French Parliament on a number of occasions during that period.

Already in 1814 Napoleon I's government commissioned Dupuytren ${ }^{21}$ to draw up a report on the question whether the grade of officier de santé could be abolished, as the facilities for medical education were now greatly improved. The University

\footnotetext{
${ }^{17}$ This provision must have been introduced in an attempt to restrict the practice of the officiers de santé to some extent and to put the onus of creating and controlling these "second-class" practitioners on the local authorities. It was, however, generally regarded as irrational and ineffective. (See Bonjean, op. cit., note 1, above, p. 262 and p. 302).

18 The loose wording of this article caused great difficulties during the whole period in which the law was in force. The exact meaning of the term grandes operations chirurgicales was never legally defined, and gave, therefore, grounds for different interpretations. Apart from the liability to be sued by the patient or his relatives in case of a serious mishap, no penalties for illegal operations had been laid down. This made it very difficult to prosecute, even for repeated offences of this nature. (See G. Tourdes, 'Responsabilité médicale', in Dechambre, op. cit., note 3 above, 3rd series, 1876, Vol. 3, pp. 681-684.)

In October 1877 M. Gallard read a paper at a meeting of the section of Hygiene, Forensic Medicine and Medical Police of the Académie de Médecine in Paris on 'Illegal operations by officiers de santé' (see Gaz. hebd, 1877, 44: 652-653). He recounted some cases where officiers de santé, in defiance of the law, had undertaken major surgical operations without medical supervision. He pointed out the danger of such practices and greatly deplored the weakness of the law which made it possible to contravene it without fear of serious legal consequences. Finally he called for an early reform of medical practice in France. For this, however, he had to wait fifteen more years for the law of 1892.

10 This provision of the law meant, at least in theory, that in case of difficulties only a fully-qualified medical man could be called in. He would have been in practice for at least eleven years, i.e. since before the old system of registration had been abolished.

${ }^{20}$ For the full text of the law see Appendix.

11 Guillaume Dupuytren (1777-1839), chief surgeon at the Hôtel de Dieu and professor of surgery at the university of Paris. He compiled the report in his capacity of inspector general of higher education.
} 


\section{Robert Heller}

Council deliberated on this question for some time without coming to any conclusion. ${ }^{22}$

In 1820 the Council of State decided that officiers de santé should only be allowed to practise after the completion of studies of four years' duration and at a minimum age of twenty-five years.

According to this move by the Council of State the draft of a law was produced. This included in addition to the above requirements, the exemption of the candidates for the officiers de santé from obtaining the diploma of bachelier ès lettres. ${ }^{23}$ This diploma had been made a compulsory condition for admission to studies leading to the degree of doctor of medicine in 1820 . The prospective law was amply debated in both houses of the French Parliament in 1825 and 1826. The most prominent speakers were Cuvier ${ }^{24}$ as Government Commissioner, and Chaptal ${ }^{25}$ reporting on the findings of the Parliamentary Commission of the Chambre des Pairs. Chaptal's proposals were eventually accepted. These were to bring about the abolition of the grade of officier de santé, replacing it with the degree of Licentiate of Medicine, conferred after four years of study. However, the change of the ministry and serious political unrest prior to the revolution of 1830 prevented these proposals being finally implemented, leaving the two-tier structure of medical practice in France undisturbed..$^{26}$

The opponents of the officier de santé grade were by no means prepared to let the matter rest without further attempts to wipe out the "second-class doctors". In 1838 a commission was set up, described by Senator Bonjean ${ }^{27}$ as "remarkable for the number and the eminence of its members". It contained representatives of the universities, the medical societies, and of the Académie de Médecine. This commission pronounced that as there were already more medical practitioners working in France than were necessary to maintain satisfactory medical care, the officier de santé grade should be abolished and the duration of medical studies should be extended to five years. This report did not result in any move by the government to amend the existing legislation, which patently needed to be brought up to date.

In 1845 a medical congress was held in Paris, which attracted a huge number of participants from all parts of France. ${ }^{28}$ The doctors declared themselves overwhelmingly in favour of the abolition of the grade of officier de sante. Parliamentary agitation against the officier de santé grade continued unabated. No fewer than twenty-one proposals for a revised law governing medical practice had been tabled between 1841 and 1847.29 Eventually a High Commission on medical studies was set up and on their advice and that of the Royal Council a new law was proposed which

\footnotetext{
22 Bonjean, op. cit., note 1 above, p. 284.

2 This diploma is loosely comparable with the old certificate of matriculation.

" Georges Leopold Cuvier (1769-1832), Professor of natural history at the Collège de France, Councillor of the Imperial University, Councillor of State, inspector of higher education.

${ }^{25}$ Jean Antoine Chaptal (1756-1832), Professor of chemistry at Montpellier and later at the Ecol polytechnique at Paris, Councillor of State and Minister of the Interior.

* Bonjean, op. cit., note 1 above, p. 284.

27 Ibid.

28 3,500 doctors and their guests were reported to have taken part. As in 1847 only about 10,600 doctors were practising in the whole of France, this figure is quite astonishing. (See A. Dechambre, 'Officier de sante' in Dechambre, op. cit., note 3 above, 2nd series, 1880, vol. 14, p. 644.)

20 Bonjean, op. cit.; note 1 above, p. 284.
} 


\section{Officiers de santé}

was to abolish the officier de santé grade and to extend medical studies to five years. It was debated at great length in six consecutive sessions of the Chambre des Pairs. The draft of the law, modified to leave the duration of medical studies at four years, was presented to the Chambre des Députés in January 1848. In February however the revolution took place and yet another plan to reform medical practice was sent back to the drawing-board on account of political upheaval..$^{30}$

The first major reform of the law of 1803 had to wait until the year 1854 to come into force. It turned out to be a feeble compromise which satisfied neither the officiers de santé nor the advocates of a university degree as the only qualification for medical practice. The grade of officier de santé was not abolished. The restriction to one département of the lesser practitioners' right to practise as laid down by the law of 1803 was reaffirmed. Before being allowed to practise in any other département they would have to repeat their examinations at their new locations. The examination boards in the different départements were abolished and the medical faculties and the écoles préparatoires de médecine et de pharmacie were assigned to examine the candidates for the lower grade. ${ }^{31}$ The entrants aiming at the lower grade had to produce some evidence of secondary education, but not up to such a high standard as the baccalaureat. There were examinations at the end of each of the first two years. The whole course took three to three and a half years, at the end of which three final examinations had to be passed. ${ }^{32}$

Although the standard of education for the grade of officier de sante had thus been raised, the existence of médecins de deuxième classe was considered by many as an anachronism and on the other hand the restriction of practice to one département was considered to be irrational by those who regarded the grade of officier de santé as a useful institution to provide medical care for the poorer classes, especially in rural areas. Eventually two diametrically opposed petitions were submitted to the French Parliament in 1864. One was to lift the geographical restrictions from the right to practise for the officier de sante, while the other asked for the abolition of the grade of officier de santé altogether. A parliamentary commission was set up to settle the question and eventually the commission's chairman Senator Bonjean submitted a full report to the French Senate at the session of 12 April 1864. ${ }^{23}$

The report first explains shortly why the commission had been set up and then gives a short historical account regarding the legislation governing medical practice and education in France, up to the date of the report. This introductory report is followed by a detailed discussion of the arguments for and against a dual medical qualification, which in effect led to the creation of medical practitioners of "first class" and of "second class". A number of the points raised in the controversy between the two opposing parties, of the doctors on the one hand and the officiers de santé on the other, are ventilated again today when the question of medical

20 Ibid.

${ }^{21}$ The écoles préparatoires de médecine et de pharmacie were attached to provincial hospitals throughout France. Students who aimed at the doctorate in medicine from a French university could pursue their studies for the first three and a half years at such a school. (See Montanier, op. cit., note 3 above, p. 648.)

"2 Recueil Sirey, op. cit., note 12 above, 2nd Series, vol. 1854, pp. 151-157.

2 Bonjean, op. cit., note 1 above. 


\section{Robert Heller}

auxiliaries is being discussed. It is, therefore, perhaps not inappropriate to look at these arguments more closely.

Senator Bonjean deals first with the points raised by Senator Cousin in favour of retention of the officier de santé grade. ${ }^{34}$ It was undeniable that every patient in France, wherever he might live, had the right to be treated by a practitioner with high qualifications, but was this feasible at the present time? 20,000 doctors were needed for the maintenance of satisfactory medical care for the whole country. To achieve this, one would need 700 new doctors to qualify each year, but the universities were unable to produce this number of graduates. Therefore one would have to content oneself with the existence of a grade of practitioners of a lower degree for the time being.

Second, one would have to consider that the doctors, used to the intellectual attractions of the larger towns, would not want to bury themselves in villages, where they would have to keep company with peasants, labourers, and other low-class people. Besides, as doctors were educated at considerable expense and as they were used to a certain standard of living, they could never be content with the small fees which the people in small rural villages could afford.

It has also been said, continues Senator Bonjean, that the common, poor people in the country needed a practitioner common and poor as they themselves who understood the language, the needs and the prejudices of his poor patients. A man of poor circumstances, used since childhood to a life in a humble cottage, who, having achieved his qualification at little expense, would be content with a modest income. The officier de santé would be in an ideal position to fulfil the role of confidant, counsellor, and comforter of the peasants, as he would almost be on an equal footing. He would be much better suited than the doctor to take his place beside the village priest and the modest village schoolmaster to complete the benevolent trinity (bienfaisant trinite) of the French villages. A doctor in a village would be just as much out of place as a graduate of the Sorbonne as a village priest, or a member of the Academy of Sciences as a village schoolmaster. Good practical medicine could be pursued without the knowledge of Greek or Latin and it was not essential to be able to read Galen and Hippocrates in the original languages. Likewise one need not know the "curiosities of science". At this point Bonjean recounts an anecdote concerning Napoleon Bonaparte's attitude towards his own doctors. When Napoleon was told that the French Académie intended to elect the savant Hallés as a member, he said "The Académie has done well to choose Hallé, but for my own person I prefer Corvisart ${ }^{36}$ even if he does not know what an isolateral triangle is."

Finally, says Bonjean, we are being told that the dissolution of the grade of officier

24 Ibid., pp. 284-285.

${ }^{25} \mathrm{Jean}$ Noel Halle (1754-1827), Professor of medical physics and public hygiene at the Collège de France. Physician to Napoleon I and later to Louis XVIII. He produced many publications, mainly on hygiene.

as Jean Nicolas Corvisart des Marest (1755-1821). He was by no means the rough and ready army doctor, as Napoleon would want him to appear. Although his secondary education might have been somewhat sketchy, he was nevertheless one of the foremost physicians of his time. He rescued Auenbrugger's Inventum novum from oblivion and by translating it into French and by adding many of his own observations introduced the general use of percussion in medical practice. His own textbook on the diseases of the heart can be regarded as a significant advance in medical knowledge. 


\section{Officiers de santé}

de santé would lead to a serious reduction in the quality of medical education, as the need for a very much larger number of fully-qualified doctors would inevitably lead to a lowering of standards. ${ }^{37}$

Subsequently Senator Bonjean deals with the arguments in favour of one single qualifying degree and of the abolition of the officier de santé grade..$^{38}$ Regarding the number of fully qualified doctors, needed, he comes to the conclusion, after examining the figures, that not more than 18,000 doctors for the whole of France would be needed to maintain satisfactory medical care throughout. On examining the figures of the new registrations, he pronounces that the grade of officier de santé might perhaps be less indispensable than some people thought and that there should be no serious difficulty in replacing them.

Next Senator Bonjean examines the question whether the grade of officier de santé was essential to ensure a more equal distribution of medical care throughout the country. Those who insisted on a system of one single qualification claimed that the image of the young doctor had been grossly distorted. The medical students were by no means grand gentlemen as they have been depicted, leading an elegant and frivolous life in the great cities, getting used to a luxurious existence. Apart from rare exceptions, they had a very modest middle-class background. Mostly they were the sons of doctors and of small property owners, who were well aware of the sacrifices their families were making on their behalf. "They worked with great ardour to attain the honorable state when they would be the consolation and pride of their aged parents." This was not done in the elegant salons of which we have heard, but in the lecture theatres, in courses at the hospital, or in the shabby attic, where the student revised today's lecture and prepared for that of tomorrow.

Senator Bonjean continues the description of the idealized life of the medical student and the young doctor. When he, after four or five years of hard work and privation finally gained the welcome diploma, he hastened to return to his place of birth, he then very often entered a marriage which had been arranged a long time ago through the loving foresight of his parents. Town or village, what did it matter to him? There he found the memories of his childhood, his friends and his sisters, so proud of their brother, the doctor. Bonjean then describes how the young doctor settles down to become a country doctor "one of the most respectable figures of the French middle class." 39 There were, of course, also those who aspired to a more spectacular career in medicine, in pursuit of science or perhaps of fame. They rarely return to their native provinces, but remain in the big towns. On the other extreme were those students who did not work at all and after a dissipated youth resigned themselves not to achieve the doctor degree. "Had not those the opportunity to become officier de santé as the examinations for that grade were less exacting?" asks Bonjean.

After this display of true Gallic eloquence the remaining points are considered in a more sober language.

${ }^{32}$ It is interesting to note that almost all the above arguments in favour of medical auxiliaries have been put forward by J. C. Reil in his book on setting up a corps of such auxiliaries, published in 1804. (See R. Heller, 'Johann Christian Reil's training scheme for medical auxiliaries', Med. Hist. 1975, 19 : 321-332.)

38 Bonjean, op, cit., note 1 above, pp. 285-288.

29 Ibid., p. 287. 


\section{Robert Heller}

Not all the officiers de santé were by any means failed doctors. There were other, more respectable reasons, for instance lack of money. This should be, Senator Bonjean thinks, of little importance, as the difference between the expenses involved was now quite small. A more serious matter than the lack of money was the lack of a suitable secondary education. Bonjean asks: "What would a liberal education be good for, if it developed only our intelligence without contributing to the development of our noble and generous sentiments?" 10 The statistics were without doubt in favour of those who wished to see a single degree qualification. On hearing the statements of those holding the opposite opinion, one would assume that all doctors were in towns and all officiers de santé were in the country and especially in the poorer areas, but nothing could be further from the truth. From time to time proposals had been made to prohibit the officiers de santé from practising in the larger towns. These proposals had always been rightly rejected as unacceptable and as being contrary to the principle of equality in our modern society. Bonjean then produces figures to prove that the officiers de santé tended to practise mainly in the rich départements in preference to the poor ones. ${ }^{41}$

Senator Bonjean then asks: Is it really true that the disappearance of the lower order of practitioners would lead to a lowering of educational standards for the higher order? He argues, that in view of the greatly improved facilities for medical education there should be no fear of any deterioration in standards.

Next the restrictions relating to the practice of the officiers de santé are examined. The one prohibiting the performance of les grandes operations chirurgicales was practically unenforceable; the other, the restriction of practice to one département was irrational. It seemed to be the only practical difference between the two grades of practitioners. These were, however, considerations of only secondary importance, the main consideration was to have the best qualified practitioners possible for the whole of the country. He quotes a passage from Flourens:42 "We should take the risk of having fewer doctors, but only real, complete, well-trained ones."4s Within only three years of medical studies and without a good secondary education in science it was impossible to produce well-qualified practitioners. For obtaining the doctor degree the extension of studies to five years was now being suggested. The continuing existence of the grade of officier de santé was being advocated on the grounds that the diseases in the country were less complicated than those in towns. Those who demanded the introduction of one single degree rejected this for three different reasons: first the officiers de santé practised by no means only in the country; second, although country-women seldom suffered from the "vapours" or other similar conditions, the serious diseases were just as serious in the country as they were in town; third, the doctor in the country had to have a good knowledge of most branches of medicine, he had to act as physician, surgeon, obstetrician, oculist, dentist, and pharmacist.

$\triangle$ Ibid.

12 Later official statistics concerning this trend will be considered below.

12 Jean Pierre Marie Flourens (1794-1867), physiologist, author and politician. Professor at the College de France and Jardin des Plantes. Permanent Secretary of the French Academy of Sciences. Parliamentary Deputy.

¿ Bonjean, op. cit., note 1 above, p. 302. 


\section{Officiers de santé}

Bonjean finally mentions that the doctor was also the adviser of the administration in all questions of public hygiene. He was also in many cases called upon to assist justice in courts of law, and that was another reason why medical practitioners needed to be well trained.

The petitions to the French Senate made by the two opposing parties came to nothing. Neither were those restraints lifted that restricted the second-class practitioners' domicile, nor was the grade of officier de santé abolished. The status quo was maintained.

The legislation concerning medical practice remained undisturbed until 1873. In this year an amendment was made to the restrictions of practice of the officier de santé grade." When moving from the département where originally registered, they were now exempted from two out of the three final examinations which they would have had to repeat. They had, however, still to pass one examination comprising clinical medicine and surgery, materia medica, and therapy. There was also a short paper to be written on a medical subject allocated by lot. The motives behind this piece of legislation seem obscure to the observer of today. It seemed to have been equally obscure to a contemporary commentator according to an editorial article in a medical journal. ${ }^{45} \mathrm{He}$ said it was immaterial whether there were three examinations or only one. The chances of registration were much the same, as anybody who could pass one, could also easily pass all three examinations. It seemed anyway to be absurd to make it more difficult for a French practitioner to move within France, than for a foreign one to obtain the right to practise on French soil. He would only have to pass one final examination and to submit a thesis. The author believed that this latest decree might have been passed on account of a shortage of medical personnel. ${ }^{46}$ It seemed, however, unlikely that such a slight easement of restrictions could have an appreciable effect in any direction. He thought that it was time for a complete reform of medical practice in France.

In 1878 the registration procedure was simplified by enabling the écoles préparatoires to issue their own diplomas to officiers de santé. ${ }^{47}$ In 1880 Dechambre reviews the situation regarding the officiers de santé again in an article of twenty-two pages. ${ }^{48}$ He bases his review in the first place on Senator Bonjean's report, ${ }^{49}$ from which he quotes some passages verbatim, but has also a great deal of his own observations to contribute. He is strongly opposed to the application of double standards in the required qualifications of medical practitioners according to whether they are treating

4 Gaz. hebd., 1873,35: 556.

"s Ibid., p. 557.

46 This shortage may have become more obvious during the Franco-Prussian war.

${ }^{47}$ In the same year a lower grade of practitioners, similar to the officiers de sante, was re-introduced in Portugal, against great opposition by the medical profession. This lower grade had originally been created under the title of cirurgioes ministrantes or licenciados minores in 1836, but was again abolished in 1842. On the re-introduction of the lower grade special three-year courses for practitioners of that grade were instituted. At that time three different classes of practitioners worked in Portugal. The doctor of medicine of the university of Coimbra, the lesser practitioner with a diploma of the same university and the physician and surgeon of the schools at Lisbon and Porto. (See A. Dureau, 'Notes sur l'enseignement et l' exercise de la médecine en Europe', Gaz. hebd, 1872, 9: 437-439.)

48 Dechambre, op. cit., notes 3 and 28 above, pp. 641-663.

- Bonjean, op. cit., note 1 above. 


\section{Robert Heller}

the well-to-do townspeople or the poor country folk. He realizes that there was a shortage of well-qualified medical personnel, but is convinced that, in view of the recent creation of new medical faculties at universities throughout France, this state of affairs would soon be rectified. He states categorically that the introduction of the officier de santé grade by the law of 1803 had failed in its purpose to provide adequate medical care for the rural population. To prove his assertions he provides us with a wealth of figures taken from official statistics. ${ }^{50}$ He states that between the years 1847 and 1876 the number of practitioners in France had fallen from 18,000 to 14,400. During this period the number of doctors had remained practically constant, rising slightly from 10,643 to 10,743 while the number of officiers de santé had fallen from 7,500 to 3,600 (see Table I). It had been assumed that the doctors would tend to practise in the towns in expectation of an easier life and of higher fees, while the poorly educated officiers de santé would automatically fill the vacancies in the country and among the poor in the towns. This however had not happened, and Dechambre's figures prove it conclusively (see Table II). He selected eight rich départements and contrasts the figures of medical practitioners with those of eight poor départements. The eight rich areas had altogether 1,208 doctors in 1866, rising slightly to 1,294 doctors in 1876. In the eight poor areas 663 doctors had been practising in 1866 and 639 in 1876. One had expected the officiers de santé to remedy this maldistribution of medical care, at least to some extent. However, we find that the rich areas had about the same number of officiers de santé as doctors, i.e. 1,294 in 1866 declining to 963 in 1876. The eight poor areas had only 113 officiers de santé in 1866 and even less in

TABLE I NUMBER OF PRACTITIONERS IN FRANCE IN 1847 AND IN $1876^{\text {s1 }}$

\begin{tabular}{|l|r|r|}
\hline \multirow{2}{*}{ Doctors } & 1847 & 1876 \\
\cline { 2 - 3 } Officiers de santé & 10,643 & 10,743 \\
& 7,456 & 3,633 \\
\hline Total & 18,099 & 14,376 \\
\hline
\end{tabular}

TABLE II NUMBER OF PRACTITONERS IN 8 RICH AND IN 8 POOR DEPARTEMENTS

\begin{tabular}{|l|c|c|c|c|}
\hline & \multicolumn{3}{|c|}{1866} & \multicolumn{2}{c|}{1876} \\
\cline { 2 - 5 } & Doctors & Off. de santé & Doctors & Off. de santé \\
\cline { 2 - 5 } 8 rich departements & 1,208 & 1,294 & 1,278 & 963 \\
8 poor departements & 663 & 113 & 639 & 83 \\
\hline
\end{tabular}

10 Dechambre, op. cit., notes 3 and 28 above, pp. 644-653.

11 Figures according to French official statistics, quoted by Dechambre, ibid., pp. 644-651.

s2 Ibid. 


\section{Officiers de santé}

1876, i.e. only 83. The rich areas had approximately one officier de santé for each doctor, but the poor ones one for every six or seven doctors respectively (see Table III). Dechambre discusses a proposal made by Flourens in 1847 to establish a grade

TABLE IIIss RATIO OF officiers de santé TO DOcTORs IN 1866 AND 1876

\begin{tabular}{|c|c|c|}
\hline $\begin{array}{l}\text { One officier de santé } \\
\text { per number of doctors }\end{array}$ & 1866 & 1876 \\
\hline $\begin{array}{l}8 \text { rich départements } \\
8 \text { poor départements }\end{array}$ & $\begin{array}{l}1 \text { to less than 1 doctor } \\
1 \text { to } 6 \text { doctors }\end{array}$ & $\begin{array}{l}1 \text { to } 1 \text { doctor } \\
1 \text { to } 7 \text { doctors }\end{array}$ \\
\hline
\end{tabular}

of licentiates, but dismisses it, as it would only lead to a similar situation of creating a two-tier system of medical practice after all. He realizes that according to the official figures, the officier de santé grade was a dying institution and that the main problem was to ensure a more equal distribution of medical manpower throughout the country. He recognizes this to be a most difficult task. In the first place he proposes as an interim measure to remove any territorial restrictions imposed on the officiers de santé grade by the law of 1803. All places short of officiers de santé should be advertised throughout the country, so that practitioners might be attracted to work in them. Dechambre himself does not seem to be too sure of the effectiveness of such a scheme. ${ }^{\text {st }}$

Finally Dechambre suggests the introduction of financial inducements for doctors to settle in the poorer areas of the country. Even the foundation of a hospital meant not only help for the poor, he says; the doctor in charge of it would also get an income from it. The communities or the départements or even the state should be prepared to pay doctors in poorer areas small annual sums to recompense them for the meagre fees they could expect from their patients. This method was simple and logical and had been in use unofficially for a long time. The author himself had on a number of occasions negotiated between the notables of a village and a young doctor intending to practise there, for a small salary or the provision of free accommodation. He saw no reason why doctors should be less well treated than ministers of religion in the country.

In the 1880s it became evident at last that the grade of "second-class practitioners" had outlived its usefulness. Legislative measures were introduced to reduce the difference between the two grades by raising the educational requirements for the lower grade. In 1883 the duration of studies for the officier de santé grade was raised to four years. In the absence of a diploma of bachelier, other evidence of a good secondary education was required prior to commencing these studies.55 In 1887 the possession of a diploma of bachelier was made compulsory for prospective students for the grade of officier de santé. Finally, on 30 November 1892 the titles of officier de santé and that of doctor of surgery were abolished. ${ }^{56}$ The article of the law which

s2 Ibid.

st Ibid., p. 659.

${ }^{55}$ Recueil Sirey, op. cit., note 12 above, vol. 1884, pp. 550-551.

so Ibid., vol. 1895, pp. 489-491. 


\section{Robert Heller}

reduced the three registrable qualifications in France to one single degree is short and concise and reads as follows:

Article 1. Nobody can practise medicine in France unless holding a diploma of doctor of medicine issued by the French Government, following examinations at an establishment of higher medical education of the State, university faculties, écoles de plein exercice and écoles preparatoires, recognized according to the regulations issued by the Superior Council for Public Instruction. The terms preceding the first two probationary examinations may be taken, and the first two examinations may be sat at an école preparatoire which has been recognized as prescribed below. ${ }^{87}$

At the time of the abolition of the lower grade of practitioners the number of its members had already been reduced to a negligible quantity. In 1891 there were only about 2,200 officiers de santé practising in the whole of France as compared with 12,300 doctors. ${ }^{58}$

In the absence of any written testimonies from the patients who had been treated by officiers de sante during the last few decades of the nineteenth century, it is impossible to judge with any degree of certainty whether or not the population at large regretted the disappearance of the lower order of practitioners. The leaders of the medical profession at the time and the majority of the fully-qualified practitioners must have felt a great sense of relief that at last the competition from that "anomaly" the officiers de santé had been removed. The teaching staff of the twenty-two écoles préparatoires, attached to provincial hospitals throughout France, looked at the abolition of the grade of second-class practitioner in an entirely different light. Having in the past trained most of the prospective officiers de santé, they had consistently resisted the abolition of that grade. They could now see their raison d'être vanish, together with their income from teaching and examining these students. The provision of the law to allow medical students to attend the écoles préparatoires for the first part of the curriculum as in the past could hardly have fully compensated for this loss. There can be little doubt that the officiers de santé had played a significant role in the medical care of the French population during the first three-quarters of the nineteenth century. They had probably been most useful in wartime, in a situation for which these practitioners were originally intended by Fourcroy. Until 1854, as only a period of apprenticeship but no formal medical studies, nor any form of secondary education had been required, the quality of their skill must have varied greatly. In times of war standards were lowered even further, to obtain badly needed medical personnel. In peacetime the poorer sections of the population must have benefited by the existence of a body of practitioners, more accessible socially and financially than the doctors. However, as the people increasingly expected to be treated by a better-qualified person and as the educational requirements for entry into the officier de santé grade were gradually raised, the supply as well as the demand for this type of medical grade diminished accordingly. The above figures show clearly that the introduction of second-class practitioners who were "good enough for the

\footnotetext{
${ }^{67}$ There was a special reason to continue the practice to allow medical students to attend the écoles préparatoires during the first part of their studies and to take examinations there. It was to keep these twenty-two schools in provincial hospitals in existence. Their teaching staff had always strongly opposed the abolition of the officier de santé grade. (See note 56 above, footnote on page 491.)

se Ibid., footnote on page 490.
} 


\section{Officiers de santé}

troops and the country folk" had not fulfilled the original expectations. In the long run it had done little to remedy the maldistribution of medical care between town and country. The problem of this imbalance is still with us today, affecting developed and developing countries alike in varying degree. Despite great efforts that are being made, we are still waiting for a system that will bring a satisfactory solution.

\section{SUMMARY}

The grade of officier de santé or médecins de deuxième classe had been created in Napoleonic France during a period of national emergency. Fourcroy, the eminent scientist and educator, one of the founders of the justly admired French system of education of the nineteenth century, was the originator of the law of 1803. This law was designed in the first place to rebuild a system of medical education and medical practice in France, which had been completely destroyed during the Revolution in 1792. Equally important was the urgent need for medical personnel for the army and navy. A two-tier system of medical practitioners was evolved: (1) doctors, having completed a conventional course of secondary education, followed by studies at a medical faculty of a university, leading to the degree of doctor of medicine, with no restrictions in the practice of medicine throughout the country; (2) on the other hand there were to be practitioners of a lower degree, the officiers de santé with a very limited secondary education, whose medical training, at least during the first fifty years after the creation of this grade, could be acquired by apprenticeship only. This grade of "second-class" practitioners, originally created as a short-lived stopgap measure, persisted for ninety years, long after it had outlived its usefulness. Only a few years after its inception the first attempts were already made to abolish this grade which remained under attack from the medical profession throughout the whole period of its existence. Political upheaval prevented every time either discussion or the final implementation of the acts of the French parliament regarding the abolition of the lower order of practitioners. The grade of officier de santé, although useful during times of war during the first half of the nineteenth century and providing some medical care for the poorer sections of the population of France, nevertheless failed to fulfil its peacetime objective of providing a more equal distribution of medical care for the rural areas. The law of 1803 is reproduced in its entirety as an appendix.

\section{APPENDIX \\ THE LAW OF 19 VENTOSE AN XI [10 MARCH 1803]}

\section{GENERAL DISPOSITIONS}

\section{Article 1.}

As from the 1st Vendémiaine of year 12 [24 September 1803]. No person can follow the profession of doctor of medicine or of surgery or that of officier de santé without having been duly examined and registered as prescribed by the present law.

\section{Article 2}

All those who will obtain, beginning from the first day of the year 12 [24 September 1803] the right to practise the art of healing will carry the title of doctor of medicine or of surgery, when they have been examined and registered at one of the six special schools of medicine, or that of officier de santé after having been admitted by the examination boards, as described in the subsequent paragraphs. 


\section{Robert Heller}

Article 3

The doctors of medicine and the surgeons, qualified at the former faculties of medicine, the colleges of surgery and the companies of surgeons (communautés de chirurgiens) will continue to possess the right to exercise the art of healing as in the past. This will also apply to those who have practised in the re-united départements by virtue of degrees obtained at foreign universities, legally recognized in the districts which constitute that particular département.

As for those who practise medicine or surgery in France and who have set up practice after the former procedures of registration had ceased to exist, they shall continue to follow their profession, either by having themselves registered as doctors or as officiers de santé according to arts. 10 and 31, or by simply fulfilling the formalities as prescribed in art. 25 of the present law.

Article 4

The government may, if it considers it suitable, accord the right to practise medicine or surgery in the territory of the Republic to a foreign physician or surgeon, graduate of a foreign university.

\section{EXAMINATIONS AND REGISTRATIONS OF DOCTORS OF MEDICINE OR SURGERY}

\section{Article 5}

At each of six special schools of medicine examinations will be started for the registration of doctors and surgeons.

\section{Article 6}

There will be five examinations as follows: the first on anatomy and physiology; the second on pathology and nosology; the third on materia medica, chemistry and pharmacy; the fourth on hygiene and forensic medicine; the fifth on external or internal clinical medicine, depending on whether the candidate wishes to acquire the degree of doctor of surgery or of medicine. The examinations will be public ones. Two of them will be, out of necessity, held in Latin.

\section{Article 7}

After the five examinations the candidate will be obliged to submit a thesis which he can write in Latin or French.

\section{Article 8}

The students will not be able to present themselves for examinations at the schools, unless they have attended one of them for four years and having paid the tuition fees which shapl be determined.

\section{Article 9}

The conditions governing the admission of students at the schools, the manner of instruction which they shall receive, the times and duration of the examinations as well as the tuition and registration fees and also the form of diploma granted by the schools to the doctors, shall be determined by a regulation which shall be given in the manner adopted for all regulations concerning public administration. However, the total sum of fees shall not exceed 1,000 Francs. This sum shall be distributed over the four years of studies and the registration.

\section{Article 10}

The physicians and surgeons who have studied before the suppression of the universities, faculties and colleges of medicine and surgery, who had not been able to take the examinations due to the said suppression and who now wish to obtain the degree of doctor shall present themselves at one of the schools of medicine with certificates regarding their studies: they shall be examined with the view of being registered; they shall only be liable to pay one-third of the fees for examination and registration.

\section{Article 11}

The physicians and surgeons not registered as described in the preceding article, who have been employed in a position of command or as officiers de santé first class during two years in the army or navy, if they wish to obtain the degree of doctor, shall present themselves at one of the schools with their patents of commission, duly certified by the ministers of war or of the navy. There they shall only be obliged to undergo the last stage of the qualifying examination, or to submit a thesis. They shall then receive a diploma and they shall pay the fees which shall be determined for the thesis only. 


\section{Officiers de santé}

Article 12

Those students who have studied at the medical schools established by the law of 14 frimaire year 3 , and who have undergone examination and have given proof of their competence at these schools according to the procedure which has been laid down, shall, if they apply to the schools where they have been examined, receive the diploma of doctor. They shall be liable to pay only half of the examination and registration fees.

\section{Article 13}

Only the national scholars chosen from the lycées or prytaneums by competitive examination for the special medical schools according to art. 35 of the law of 11 floreal year 10 shall be exempt from paying tuition and registration fees.

\section{Article 14}

The income derived from the tuition and registration fees of each school of medicine shall be used for the salaries of the professors and for defraying the expenditure of each [school], as shall be determined by the government. However, the money received by one school shall not be used to cover the expenditure of any other.

\section{STUDIES AND REGISTRATION OF officiers de santé}

\section{Article 15}

The young men intending to become health officers shall not be obliged to study at medical schools; they shall be registered as officiers de santé after six years of having attended doctors as their pupils, or having had five consecutive years of practical instruction in civilian or military hospitals. A period of studies at a medical school of three consecutive years shall be deemed equal to residence with a doctor for six years or at a hospital for five years.

\section{Article 16}

For the registration of officier de sante there shall be examination boards established in the principal town of each département, consisting of two doctors, domiciled in the département, nominated by the First Consul and a commissioner, chosen from the professors of the six medical schools and designated by the First Consul. These boards shall be re-appointed every five years, but the individual members shall be eligible to continue in office.

\section{Article 17}

The boards shall hold examinations for the registration of officier de santé once yearly. There shall be three examinations; the first on anatomy; the second on the elements of medicine; the third on surgery and on some general knowledge of pharmacy. The examinations shall be held in French and on premises where the public can be admitted.

\section{Article 18}

In the six départements in which the medical schools will be situated, the members of the examination boards shall be appointed from among their professors and the officiers de santé shall be admitted to the practice within their territories.

\section{Article 19}

The examination fees for the prospective officiers de santé shall not exceed 200 Francs. The distribution of the monies among the members of the examination boards shall be determined by the government.

\section{Article 20}

The manner in which the examinations shall be conducted by the boards, the time when they shall be held, their duration as well as the form of diploma to be awarded to the officiers de santé shall be determined by regulation, according to art. 9 .

\section{Article 21}

Those persons who have established themselves during the past ten years in the villages and towns to practise surgery, without having been able to be registered after the suspension of the lieutenancy of the premier chirurgien and of the surgeons' companies, may present themselves before the examination 


\section{Robert Heller}

boards to be examined and registered as officiers de santé. They will only pay one-third of the examination fees.

\section{REGISTRATION AND LISTS OF DOCTORS AND officiers de santé}

\section{Article 22}

The doctors and surgeons permitted to practise according to the former procedures, now suppressed in France, or according to the regulations which existed in the re-united départements, shall present their letters of admission or of freedom of a surgeons' company within three months of the publication of this law, at the tribunal of their district and at the office of their sous-prefect. An entry in a list formerly legally recognized, or if the entry or the list itself is missing, an attestation of three doctors or three surgeons with legally recognized titles, given before a tribunal, shall be sufficient for those doctors or surgeons who have lost and cannot therefore produce their documents of admission or freedom of a surgeons' company.

\section{Article 23}

The physicians or surgeons, established after the suppression of the universities, faculties, colleges and societies, without having been able to have themselves registered and who have practised for three years, shall obtain a certificate from the Sub-Prefect of their district on attestation of the Mayor and of two notables of the community where they reside who have been chosen by the Sub-Prefect; this certificate, which shall state that they have practised their art for the period indicated, shall serve them instead of the diploma of officier de sante; they shall present it within the period of time as prescribed in the preceding article at the tribunal of their district and at the office of their Sub-Prefecture. The conditions of this article shall also apply to persons mentioned in arts. 10 and 11 and equally to those who were neither employed in a position of command nor of first-class officers in the army or navy, having served for three years, not taking the title of doctor of medicine or surgery.

\section{Article 24}

The doctors or officiers de santé registered according to the procedures laid down in the preceding two sections, shall be obliged to present, within one month of having taken up their domicile, the diplomas which they shall have received, at the registry office of the tribunal of the first instance and at the office of the Sub-Prefect of the district, where the doctors and officiers de sante wished to establish themselves in practice.

\section{Article 25}

The governmental commissaries at the tribunals of the first instance shall prepare the lists of the physicians and surgeons formerly registered, of those established for six years without having been admitted and of the doctors and officiers de santé newly registered according to the provisions of the present law, registered at the offices of these tribunals; in Fructidor of each year they shall send certified copies of these lists to the Grand Judge, the Minister of Justice.

\section{Article 26}

The Sub-prefects shall send copies of the registration of the previous certificates and of the new diplomas as mentioned above, to the Prefects who shall compile and publish the lists of all the physicians and surgeons previously registered and of the doctors and officiers de santé within their départements. These lists shall be sent by the Prefects to the Minister of the Interior during the last month of the year.

\section{Article 27}

With effect from the date of publication of the present law, the function of doctors and surgeons sworn in and appointed by the tribunals, that of physicians and surgeons in charge of civilian hospitals or charged by administrative authorities with diverse activities regarding public health, can only be fulfilled by physicians or surgeons duly registered according to the former procedures or by doctors registered according to the present law.

\section{Article 28}

The doctors registered through the medical schools may practise their profession in any of the communities of the Republic, provided they comply with the provisions as laid down in the preceding articles. 


\section{Officiers de santé}

Article 29

The officiers de santé shall only establish themselves in practice within the département where they have been examined by the examination board, after having been registered as it shall be prescribed. They shall not be able to perform major surgical operations (les grandes operations chirurgicales) unless under the supervision of a doctor from the same locality where he himself shall have established his practice. In the case of a serious mishap arising from an operation performed without supervision and inspection as prescribed above, one shall have recourse to claim an indemnity from the Officier de sante guilty of the offence.

\section{TRAINING AND REOISTRATION OF MIDWIVES}

\section{Article 30}

Further to the instruction given within the medical schools, there shall be established in the most frequented lying-in hospital (hospice) of each département a yearly, free, training course of theoretical and practical midwifery, designed particularly for the instruction of midwives. The salaries and the cost of the course shall be defrayed from the income derived from the fees for the registration of the officiers de santé.

\section{Article 31}

The pupil midwives shall attend at least two of these courses and have observed the practice of midwifery for nine months or have practised it themselves for six months, either in an hospice or under the supervision of a teacher before they shall present themselves for examination.

\section{Article 32}

They shall be examined by the examination boards on the theory and practice of midwifery and on the mishaps that might occur before, during and after confinement and on the ways to deal with them. To those who shall have satisfied the examiners, a diploma shall be awarded free of charge the details of which shall be determined by the regulation, prescribed in arts. 9 and 20 of the present law.

\section{Article 33}

The midwives shall register their diplomas at the tribunal of the first instance and at the subprefecture of the district where they shall establish themselves and where they shall be admitted. The list of midwives who have been admitted shall, for each département, be prepared by the tribunal of the first instance and by the Prefects according to the procedure laid down in arts. 25 and 26 above.

\section{GENERAL DISPOOSTIONS}

\section{Article 35}

Six months after the publication of the present law, all persons who continue to practise medicine and surgery or to practise the art of midwifery, without being on the lists as described in arts. 25, 26 and 34 and without possessing a diploma, certificate or letters of admission, shall be prosecuted and sentenced to pay a fine, which shall go towards the upkeep of hospices.

\section{Article 36}

Such offence shall be notified to the tribunal of the police, dealing with misdemeanors (police correctionelle), for the attention of the government commissary at that tribunal.

The fine imposed can be up to 1,000 Francs for those who shall assume the title and practise as doctors. Up to 500 Francs for those who call themselves officiers de santé and deal with patients in that capacity. Up to 100 Francs for women who practise the art of midwifery illicitly. The fine shall be double in case of a second offence and the delinquent shall also be liable to a term of imprisonment not exceeding six months.

\section{ACKNOWLEDGEMENTS}

I should like to thank Professor Erwin H. Ackerknecht, Zürich, for his advice, Mr. W. A. Steiner, Librarian, Institute for Advanced Legal Studies, London, for providing information on French legislation, and especially Mr. Eric Freeman, Librarian, Wellcome Institute for the History of Medicine, London, for his continuous help and advice. 